\title{
Short communication: Association of milk fatty acids with early lactation hyperketonemia and elevated concentration of nonesterified fatty acids
}

\author{
S. Mann, ${ }^{* 1}$ D. V. Nydam, ${ }^{*}$ A. L. Lock, $\dagger$ T. R. Overton, $\ddagger$ and J. A. A. McArt ${ }^{*}$ \\ *Department of Population Medicine and Diagnostic Sciences, College of Veterinary Medicine, Cornell University, Ithaca, NY 14853 \\ †Department of Animal Science, Michigan State University, East Lansing 48824 \\ ‡Department of Animal Science, Cornell University, Ithaca, NY 14853
}

\section{ABSTRACT}

The objective of our study was to extend the limited research available on the association between concentrations of milk fatty acids and elevated nonesterified fatty acids (NEFA) and $\beta$-hydroxybutyrate (BHB) concentrations in early lactation dairy cattle. Measurement of milk fatty acids for detection of cows in excessive negative energy balance has the potential to be incorporated in routine in-line monitoring systems. Blood samples were taken from 84 cows in second or greater lactation 3 times per week between 3 to $14 \mathrm{~d}$ in milk. Cows were characterized as hyperketonemic (HYK) if blood BHB concentration was $\geq 1.2 \mathrm{mmol} / \mathrm{L}$ at least once and characterized as having elevated concentrations of NEFA $\left(\mathrm{NEFA}_{\mathrm{H}}\right)$ if serum NEFA concentration was $\geq 1 \mathrm{mmol} / \mathrm{L}$ at least once. Composition of colostrum and milk fatty acids at wk 2 postpartum was used to investigate the potential diagnostic value of individual fatty acids and fatty acid ratios for the correct classification of cows with NEFA and BHB concentrations above these thresholds, respectively. Receiver operating characteristic (ROC) curves were used to identify thresholds of fatty acid concentration and fatty acid ratios when ROC area under the curve was $\geq 0.70$. Correct classification rate $(\mathrm{CCR}, \%)$ was calculated as $\{[($ number of true positives + number of true negatives)/total number tested] $\times 100\}$. None of the colostrum fatty acids yielded a sufficiently high area under the curve in ROC analysis for the association with HYK and $\mathrm{NEFA}_{\mathrm{H}}$. The following fatty acids and fatty acid ratios were identified for an association with NEFA $_{\mathrm{H}}$ (threshold, CCR): C15:0 $(\leq 0.65 \mathrm{~g} / 100$ g, $68.3 \%$ ); cis-9 C16:1 ( $\geq 1.85 \mathrm{~g} / 100 \mathrm{~g}, 70.7 \%$ ); cis-9 C18:1 ( $\geq 26 \mathrm{~g} / 100 \mathrm{~g}, 69.5 \%$ ), cis-9 $\mathrm{C} 18: 1$ to C15:0 ratio ( $\geq 45,69.5 \%)$; cis-9 $\mathrm{C} 16: 1$ to $\mathrm{C} 15: 0(\geq 2.50,73.2 \%)$. Several fatty acids were associated with HYK (thresh-

Received January 20, 2016.

Accepted March 28, 2016.

${ }^{1}$ Corresponding author: sm682@cornell.edu old, CCR): C6:0 ( $\leq 1.68 \mathrm{~g} / 100 \mathrm{~g}, 80.5 \%)$, C8:0 $(\leq 0.80$ $\mathrm{g} / 100 \mathrm{~g}, 80.5 \%)$, C10:0 ( $\leq 1.6 \mathrm{~g} / 100 \mathrm{~g}, 79.3 \%) ; \mathrm{C} 12: 0$ $(\leq 1.42 \mathrm{~g} / 100 \mathrm{~g}, 82.9 \%)$; C14:0 ( $\leq 6.10 \mathrm{~g} / 100 \mathrm{~g}, 84.1 \%)$; C15:0 ( $\leq 0.50 \mathrm{~g} / 100 \mathrm{~g}, 82.9 \%)$, cis-9 C18:1 ( $\geq 30 \mathrm{~g} / 100$ $\mathrm{g}, 81.7 \%)$. The use of fatty acid ratios did not improve CCR over using individual fatty acids for the classification of HYK. Colostrum fatty acid composition was not useful in predicting $\mathrm{NEFA}_{\mathrm{H}}$ or $\mathrm{HYK}$ between 3 to 14 $\mathrm{d}$ in milk. Accuracy of milk fatty acids and fatty acid ratios to correctly classify cows with elevated concentrations of NEFA and BHB between 3 to $14 \mathrm{~d}$ in milk was moderate and overall higher for HYK. Determining changes in the fatty acid composition of milk fat from milk samples at wk 2 postpartum for the detection of cows with elevated concentrations of BHB and NEFA can currently not be recommended to replace direct measurement. Future applications should target repeated milk sampling between 3 to $14 \mathrm{~d}$ in milk to identify the best sampling for determination of milk fatty acid composition within the first 2 wk postpartum.

Key words: milk fatty acid, metabolism, diagnosis, transition cow

\section{Short Communication}

The onset of lactation and concurrent drop in DMI during the transition period in dairy cows is associated with a period of negative energy balance (NEB), which is most severe in the first weeks postpartum. Epidemiological data have established the association between increased blood concentrations of markers of NEB, such as BHB and nonesterified fatty acids (NEFA), and negative health and production outcomes at both the individual cow and herd level (Duffield et al., 2009; Ospina et al., 2010, 2013).

Whereas measurement of blood BHB concentrations can be carried out cow-side with several different hand-held meters (Iwersen et al., 2009, 2013; Mahrt et al., 2014), NEFA is currently measured in a laboratory setting only. Although NEFA concentrations are a direct measure of net adipose tissue mobilization, de- 
termination of serum NEFA concentrations is therefore more costly and associated with a substantial lag time compared with BHB measurements, which has hampered knowledge regarding the benefits of individual identification and treatment of cows with high concentrations of NEFA. The large amount of epidemiological data concerning the association of negative health and production outcomes with BHB and NEFA as markers of NEB on the herd level have increased interest in onfarm measurement. Particularly, the search for testing methods not requiring blood sampling that could be incorporated into the daily milking routine with simple, fast, and inexpensive methods has increased (Hamann and Krömker, 1997; Barbano et al., 2015). Researchers have focused on milk composition (fat and protein) for several years using the ratio of fat to protein as a herdlevel screening tool for lipomobilization, NEB, and hyperketonemia (HYK; Duffield et al., 1997; Krogh et al., 2011; Toni et al., 2011). However, this method does not take the variability in different milk fatty acids into account. Because the elevation of certain milk fatty acids originating from adipose tissue mobilization is associated with the degree of NEB and HYK (Van Haelst et al., 2008; Gross et al., 2011; Barbano et al., 2015), studying the association of markers of NEB with milk fatty acid profile is of particular importance.

Recently, Jorjong et al. (2014, 2015) proposed cut-off values of milk fatty acids and milk fatty acid ratios for the early diagnosis of elevated blood plasma concentrations of NEFA and as biomarkers for HYK. However, cows were only sampled once per week in this study (Jorjong et al., 2014, 2015), and classification of cows was based on concentrations of NEFA and BHB in wk 2 to 8 postpartum, possibly leading to an underestimation of the incidence of an increase of these markers above established thresholds, as discussed by the authors. Because incidence of HYK peaks around 4 to 5 $\mathrm{d}$ postpartum and the median length of an episode of HYK is 5 d (McArt et al., 2012; McCarthy et al., 2015), case detection is improved through frequent sampling of cows, particularly in wk 1 and 2 postpartum. In addition, NEFA concentrations are highest during the first 2 wk of lactation (McCarthy et al., 2015). Our objective was therefore to extend the research already available and examine the association between concentrations of milk fatty acids with elevated NEFA and BHB concentrations during the highest at-risk period between 3 and 14 DIM, and to compare threshold values established by receiver operating characteristic (ROC) curves to those proposed in the studies by Jorjong et al. (2014, 2015).

Data and samples originated from the experiment described in detail in Mann et al. (2015) studying the effect of different nutritional planes of energy during the dry period. All cows with colostrum milk fatty acid data were included in the current study. A detailed description of diets, DMI, milk production, and fatty acid analysis has previously been described (Mann et al., 2015), and the detailed analysis of colostrum samples can be found elsewhere (Mann et al., 2016). In brief, blood samples were taken from the coccygeal vessels 3 times per week before the morning feeding and analyzed cow-side for BHB concentration using a handheld device (Precision Xtra meter, Abbott Diabetes Care Inc., Alameda, CA), whereas serum was analyzed for NEFA concentration using a colorimetric measurement of an enzymatic reaction [HR Series NEFA-HR (2), Wako Life Sciences, Mountain View, CA]. Cows were considered positive for HYK if one or more samples yielded a BHB concentration of $\geq 1.2 \mathrm{mmol} / \mathrm{L}$ between 3 to 14 DIM. Cows were considered as having elevated concentrations of serum NEFA $\left(\mathbf{N E F A}_{\mathbf{H}}\right)$ when concentrations were $\geq 1.0 \mathrm{mmol} / \mathrm{L}$ for one or more samples between 3 to 14 DIM and otherwise classified as having low concentrations $\left(\mathbf{N E F A}_{\mathbf{L}}\right)$. Colostrum samples as well as a composite sample of morning and afternoon milk samples from the second week after calving were analyzed for fatty acid composition as previously described (Lock et al., 2013).

Univariable logistic regression analysis was carried out with the binary dependent variables $\mathrm{HYK} /$ non$\mathrm{HYK}$ and $\mathrm{NEFA}_{\mathrm{H}} / \mathrm{NEFA}_{\mathrm{L}}$, respectively, where $\mathrm{HYK}$ and $\mathrm{NEFA}_{\mathrm{H}}$ were considered as test positive outcomes. Each fatty acid or fatty acid ratio was screened using the statistical software package JMP (v. 11.0; SAS Institute Inc., Cary, NC) for an area under the curve (AUC) of the ROC curve $\geq 0.70$, which was considered a useful cut-off according to Swets (1988). The closer the ROC AUC gets to 1, the more accurate the fatty acid threshold is in correctly classifying cows in each group. Ratios of fatty acids included those between cis9 C18:1 and C15:0 as proposed by Jorjong et al. (2014, 2015) as well as between those fatty acids with ROC AUC $\geq 0.70$ that were increased in $\mathrm{HYK}$ or $\mathrm{NEFA}_{\mathrm{H}}$ with C15:0 (Jorjong et al., 2014, 2015). Threshold values were determined based on the concentrations and ratios that yielded maximum sensitivity and specificity as previously described (Ospina et al., 2010). Sensitivity, specificity, and positive and negative predictive values were calculated after classification of cows according to the established threshold values identified by our analysis. In addition, those thresholds proposed by Jorjong et al. $(2014,2015)$ were also evaluated. The accuracy of the test was calculated as the correct classification rate $(\mathrm{CCR}, \%)=\{[$ (number of true positives + number of true negatives)/total number tested] $\times 100\}$.

In addition to using fatty acid ratios to improve accuracy, and because of the interest in having the high- 
est possible sensitivity to correctly detect cows with elevated concentrations of NEFA and BHB, we also calculated the combined sensitivity, specificity, and predictive values when testing the 2 fatty acids with the highest accuracy in parallel for $\mathrm{NEFA}_{\mathrm{H}}$ and $\mathrm{HYK}$, respectively, using the test with the higher sensitivity first. Testing in parallel is a strategy to improve the overall sensitivity of testing, but decreases specificity (Dohoo et al., 2009).

A total of 83 samples were available for colostrum fatty acid profile and 82 samples for wk 2 of lactation. The average day (SD) of sampling for wk 2 was 10.2 (2.3) d postpartum. Of the 83 samples for colostrum, 26 (31.3\%) were from HYK and 57 (68.7\%) from non-HYK cows; $40(48.2 \%)$ were from $\mathrm{NEFA}_{\mathrm{H}}$ and $43(51.8 \%)$ from $\mathrm{NEFA}_{\mathrm{L}}$ cows. For wk 2 milk samples, $25(30.5 \%)$ were from the HYK group, the remaining 57 (69.5\%) were from the non-HYK group, and 39 (47.5\%) were from the $\mathrm{NEFA}_{\mathrm{H}}$ group, whereas 43 were from $\mathrm{NEFA}_{\mathrm{L}}$ $(51.8 \%)$. Out of the $25 \mathrm{HYK}$ classified cows, 19 were also $\mathrm{NEFA}_{\mathrm{H}},(76.0 \%)$. Table 1 depicts the fatty acids and fatty acid ratios screened and ROC AUC for the outcome of HYK and $\mathrm{NEFA}_{\mathrm{H}}$, respectively.

None of the evaluated fatty acids in colostrum reached a ROC AUC of $\geq 0.70$ for the outcome of HYK or $\mathrm{NEFA}_{\mathrm{H}}$, respectively. Among the fatty acids that were screened in milk samples from wk 2, C15:0, cis-9 C16:1 and cis-9 C18:1, as well as the ratios cis-9 C18:1 to $\mathrm{C} 15: 0$ and cis-9 C16:1 to C:15:0 yielded ROC AUC $\geq 0.70$ for the outcome $\mathrm{NEFA}_{\mathrm{H}}$. Distribution of each fatty acid and the ratio in the different groups of NEFA concentration as well as the calculated test sensitivity, specificity, and predictive values at the threshold identified by ROC are shown in Table 2 . Sensitivity (the true positive rate) ranged from 61.5 to $97.4 \%$ whereas specificity (the true negative rate) ranged from 34.9 to $79.1 \%$ depending on the fatty acid and threshold value chosen. The positive predictive value was highest (76.1\%) for the cis-9 C18:1 threshold of $24 \mathrm{~g} / 100 \mathrm{~g}$ proposed by Jorjong et al. (2014). However, this threshold was also associated with the lowest negative predictive value of $41.7 \%$, meaning that negative tests would have

Table 1. List of fatty acid in colostrum and milk and fatty acid ratios screened in postpartum Holstein cows $(\mathrm{n}=82)$ for their association with $\mathrm{NEFA}_{\mathrm{H}}$ and hyperketonemia $(\mathrm{HYK})^{1}$

\begin{tabular}{|c|c|c|c|c|}
\hline \multirow[b]{2}{*}{ Item } & \multicolumn{2}{|c|}{ ROC AUC HYK } & \multicolumn{2}{|c|}{ ROC AUC $\mathrm{NEFA}_{\mathrm{H}}$} \\
\hline & Colostrum & Milk Wk 2 & Colostrum & Milk Wk 2 \\
\hline \multicolumn{5}{|l|}{ Fatty acid } \\
\hline $\mathrm{C} 4: 0$ & 0.61 & 0.49 & 0.55 & 0.64 \\
\hline $\mathrm{C} 6: 0$ & 0.53 & $0.72^{2}$ & 0.49 & 0.59 \\
\hline C8:0 & 0.52 & $0.75^{2}$ & 0.48 & 0.63 \\
\hline C10:0 & 0.59 & $0.79^{2}$ & 0.51 & 0.67 \\
\hline $\mathrm{C} 12: 0$ & 0.51 & $0.80^{2}$ & 0.53 & 0.69 \\
\hline $\mathrm{C} 14: 0$ & 0.59 & $0.82^{2}$ & 0.53 & 0.69 \\
\hline cis-9 C14:1 & 0.58 & 0.56 & 0.53 & 0.56 \\
\hline $\mathrm{C} 15: 0$ & 0.60 & $0.89^{2}$ & 0.55 & $0.74^{2}$ \\
\hline C16:0 & 0.60 & 0.66 & 0.53 & 0.63 \\
\hline cis-9 C16:1 & 0.58 & $0.77^{2}$ & 0.53 & $0.75^{2}$ \\
\hline $\mathrm{C} 17: 0$ & 0.51 & 0.68 & 0.53 & 0.57 \\
\hline C18:0 & 0.60 & 0.65 & 0.52 & 0.52 \\
\hline trans-9 C18:1 & 0.53 & 0.60 & 0.57 & 0.56 \\
\hline trans-10 C18:1 & 0.53 & 0.69 & 0.51 & 0.54 \\
\hline trans-11 C18:1 & 0.47 & 0.53 & 0.53 & 0.57 \\
\hline trans-12 C18:1 & 0.56 & 0.69 & 0.50 & 0.47 \\
\hline cis-9 C18:1 & 0.58 & $0.83^{2}$ & 0.52 & $0.71^{2}$ \\
\hline cis-11 C18:1 & 0.59 & 0.67 & 0.55 & 0.62 \\
\hline cis-12 C18:1 & 0.62 & 0.61 & 0.53 & 0.55 \\
\hline cis-9,cis-12 C18:2 & 0.57 & 0.51 & 0.48 & 0.56 \\
\hline cis-9,trans-11 C18:2 & 0.53 & 0.66 & 0.55 & 0.60 \\
\hline cis-9,cis-12,cis-15 C18:3 & 0.57 & 0.66 & 0.54 & 0.51 \\
\hline \multicolumn{5}{|l|}{ Fatty acid ratio } \\
\hline cis-9 C18:1 to C15:0 & - & $0.89^{2}$ & - & $0.75^{2}$ \\
\hline cis-9 $\mathrm{C} 16: 1$ to $\mathrm{C} 15: 0$ & - & $0.88^{2}$ & - & $0.78^{2}$ \\
\hline
\end{tabular}

${ }^{1}$ Approximately 70 individual fatty acids were quantified. Only select fatty acids are reported. Resulting receiver operating characteristic (ROC) areas under the curve (AUC) are shown for the positive outcome HYK and $\mathrm{NEFA}_{\mathrm{H}}$. $\mathrm{NEFA}_{\mathrm{H}}=$ at least one event of serum concentration of nonesterified fatty acids $\geq 1.0 \mathrm{mmol} / \mathrm{L}$ between 3 and 14 DIM. HYK = at least one event of whole blood concentration of BHB $\geq 1.2 \mathrm{mmol} / \mathrm{L}$ between 3 and 14 DIM.

${ }^{2}$ Fatty acids and fatty acid ratios with ROC AUC $\geq 0.70$ were further evaluated for thresholds. 
been from animals with truly low NEFA concentrations between 3 to 14 DIM less than $50 \%$ of the time. The accuracy reached a maximum of $73.2 \%$ for the threshold of $2.5 \mathrm{~g} / 100 \mathrm{~g}$ of the ratio cis-9 C16:1 to C15:0 (Table 2).

Among those fatty acids screened for the association with HYK in milk samples from wk 2, a total of 8 fatty acids and 2 fatty acid ratios yielded a ROC AUC $\geq 0.70$ as shown in Table 1. Sensitivity ranged from 52.0 to $84.0 \%$, whereas specificity ranged from 63.2 to $98.2 \%$. The highest positive predictive value $(92.9 \%)$ was found for a threshold $\leq 6.10 \mathrm{~g} / 100 \mathrm{~g}$ of C14:0, and the highest negative predictive value $(90.4 \%)$ for a threshold $\geq 54$ $\mathrm{g} / 100 \mathrm{~g}$ of the ratio cis-9 C18:1 to C15:0. Accuracy was highest ( $86.6 \%$ ) for the threshold $\geq 3.76 \mathrm{~g} / 100 \mathrm{~g}$ of cis -9 C16:1 to C15:0 (Table 3).

The results of our study show that the test accuracy for selected fatty acids from milk samples in wk 2 of lactation reached a maximum of $73.2 \%$ for the correct classification of cows into low and high NEFA groups (fatty acid ratio cis-9 C16:1 to C15:0) and the same ratio was higher at $86.6 \%$ for the classification of cows into the correct HYK group. Hence, 26.8 and $13.4 \%$ of cows, respectively, were misclassified for the 2 outcomes of interest using the fatty acids or fatty acid ratio with the highest accuracy in this study. The overall accuracy is at a similar but lower level than what was previously described by Jorjong et al. (2014) for NEFA concentrations above $0.6 \mathrm{mmol} / \mathrm{L}(78.8 \%$ accuracy for a threshold of $24 \mathrm{~g} / 100 \mathrm{~g}$ of C18:1 cis-9) and by Jorjong et al. (2015) for HYK (82.3\% accuracy for a threshold of the ratio $\mathrm{C} 18: 1$ cis-9-to-C15:0 of $\geq 45)$.

Based on the increased frequency of sampling in this study, we chose a more conservative threshold value of $1.0 \mathrm{mmol} / \mathrm{L}$ (Chapinal et al., 2011) for the classification of cows into NEFA categories as compared with the threshold of $0.6 \mathrm{mmol} / \mathrm{L}$ used by Jorjong et al. (2014). In fact, mean NEFA concentrations during the first 2 wk ranged from 0.6 to $0.8 \mathrm{mmol} / \mathrm{L}$ for the different prepartum treatment groups in our study (Mann et al., 2015), whereas in the study by Jorjong et al. (2014) mean NEFA concentrations in wk 2 ranged from 0.2 to $0.4 \mathrm{mmol} / \mathrm{L}$. Of all the observations in wk $2,3,4$, and 8 in the study by Jorjong et al. (2014), $8 \%$ were $\geq 0.6 \mathrm{mmol} / \mathrm{L}$ compared with $47.5 \% \geq 1.0 \mathrm{mmol} / \mathrm{L}$ in our study of 3-times-per-week samples between 3 to 14 DIM. It should be noted that the commonly used postpartum threshold concentrations for both NEFA and BHB were evaluated in a cross-sectional study (Ospina et al., 2010; Suthar et al., 2013) or using weekly blood samples (Duffield et al., 2009; Chapinal et al., 2011) and were not evaluated using more frequent sampling in early lactation.

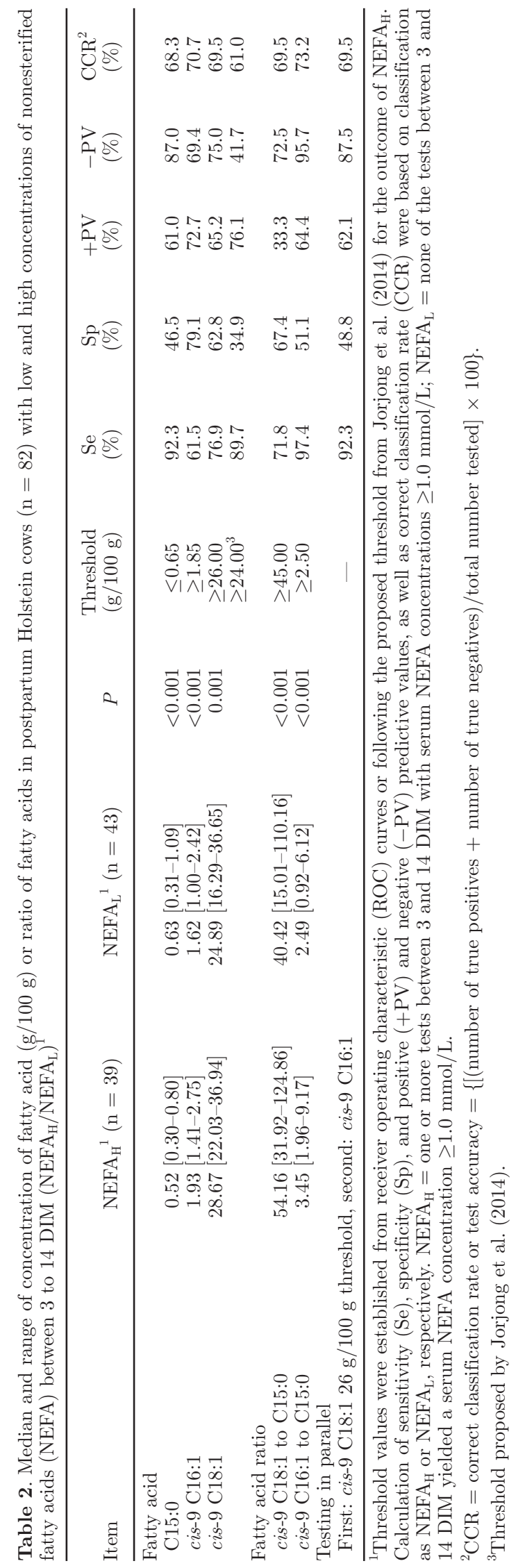




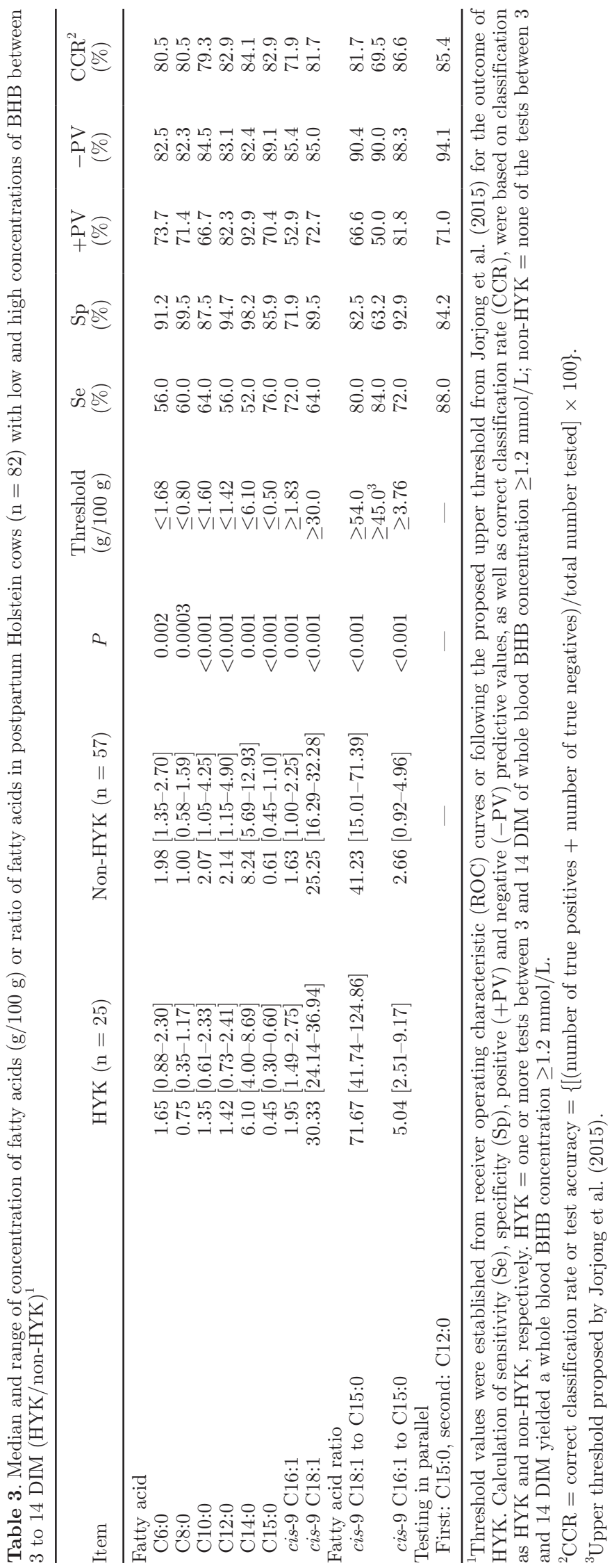

In the present study, cis-9 $\mathrm{C} 16: 1$ and the ratio of cis9 C16:1 to C15:0 had the highest accuracy of all fatty acids and fatty acid ratios for the correct classification of NEFA. The conversion of C16:0 to cis-9 C16:1 is regulated in the same way as the conversion of $\mathrm{C} 18: 0$ to cis-9 $\mathrm{C} 18: 1$ by the enzyme $\Delta^{9}$-desaturase in lactating mammary cells (Bauman et al., 1999, 2006; Palmquist, 2006), although the most common substrate is C18:0 (Palmquist et al., 2005). Absorption of cis-9 C16:1 from the diet is limited due to low dietary intake and rumen biohydrogenation, which may pose an advantage in the use of this fatty acids compared with cis-9 C18:1 because cis-9 $\mathrm{C} 18: 1$ is found in higher amounts in ruminant feedstuffs (Harfoot, 1981). The concentration of C16:0, C18:0, and cis-9 C18:1 in plasma NEFA of postpartum dairy cows is high, and together these fatty acid account for approximately $80 \%$ of plasma NEFA in the first week postpartum (Contreras et al., 2010). This helps to explain the relationship between cis-9 C16:1 and cis-9 C18:1 in milk fat and elevated NEFA concentrations found in this study.

Despite differences in NEFA concentrations and methodology between the study by Jorjong et al. (2014) and our own, we also identified cis-9 C18:1 as one of the fatty acids with the highest discriminatory ability among all fatty acids screened. The increase in this milk fatty acid is associated with a higher degree of adipose tissue mobilization and excessive NEB (Nogalski et al., 2012) and cis-9 C18:1 is the predominant fatty acid in ruminant adipose tissue (Gillis et al., 1973). The combined sensitivity and specificity was improved by using a higher threshold of $26 \mathrm{~g} / 100 \mathrm{~g}$ as opposed to $24 \mathrm{~g} / 100 \mathrm{~g}$ proposed by Jorjong et al. (2014). Interestingly, the ratio of cis-9 C18:1 to C15:0 did not improve diagnostic accuracy over using cis-9 C18:1 alone, and C15:0 at a threshold of $\leq 0.65 \mathrm{~g} / 100 \mathrm{~g}$ was associated with the highest ROC AUC in our analysis. The C15:0 originates from microbial synthesis from propionate in the rumen (Harfoot, 1981), whereas mammary gland de novo synthesis following incorporation of propionyl$\mathrm{CoA}$ or methylmalonyl-CoA is negligible (Vlaeminck et al., 2006). This is of importance as C15:0 is also the fatty acid with the highest ROC AUC we identified for the association with HYK, albeit at a lower threshold of $\leq 0.5 \mathrm{~g} / 100 \mathrm{~g}$. Several de novo fatty acids (C6:0, C8:0, C10:0, C12:0, 14:0) were associated with HYK status, which is reflective of the state of NEB when de novo fatty acid synthesis in adipose tissue and the mammary gland is decreased (Gross et al., 2011). In the study by Jorjong et al. (2015), the cis-9 C18:1 to C15:0 ratio at a threshold of $>45$ was identified as the variable with the highest overall classification accuracy for HYK. Our study also identified this ratio at a higher threshold of 54.0, which led to an increased accuracy of 
$81.7 \%$ as compared with $69.5 \%$ at a ratio of 45 . Overall, the use of fatty acid ratios did not meaningfully improve the accuracy for the correct classification of HYK over using selected fatty acids alone or over using a testing-in-parallel strategy. The fatty acid composition of colostrum showed no association with elevated concentration of NEFA and BHB between 3 to 14 DIM, thus colostral fatty acid composition cannot be used as an early detection tool to predict excessive NEB.

In light of our current results, we conclude that milk fatty acids in wk 2 of lactation do not represent highly accurate tests for the association with elevated NEFA and BHB concentrations in early lactation. In addition, data were generated from a cohort of cows fed the same ration and managed in the same way, which likely limited variability in milk fat composition in the study population. It was recently shown that bulk milk samples from different herds differ in milk fatty acid profile depending on several management factors, including feeding frequency, stocking density, and body condition (Woolpert et al., 2015). The availability of only one time point around 10 DIM in this study clearly limited our ability to use milk fatty acid concentrations to predict an excessive increase in NEFA or BHB concentrations as temporality between an increase in both markers of NEB and an increase in fatty acid concentrations could not be ascertained due to the absence of more repeated milk sampling. Future studies should target repeated determination of milk fatty acid composition between 3 and 14 DIM to be able to establish temporal associations and evaluate the ability to use milk fatty acids as predictors of excessive NEB with higher accuracy than based on this and previous work.

Most studies on the association between fatty acid composition and markers of NEB have been carried out with costly methodologies that lack applicability on dairy farms and are not routinely available (Gross et al., 2011; Jorjong et al., 2014, 2015). With the potential of mid-infrared spectrometry predictions to integrate milk fatty acid composition directly in the milking system (Barbano et al., 2014), the possibility of future routine use of this information has increased. The ability to use milk fatty acid concentration for the early diagnosis of elevated concentrations of NEFA and BHB using the fatty acids identified in this study should be tested across more time points in different data sets to determine the usefulness of the proposed fatty acids and fatty acid ratio thresholds.

\section{ACKNOWLEDGMENTS}

This project was supported by the Agriculture and Food Research Initiative competitive grant no. 2012-
67015-30230 from the USDA National Institute of Food and Agriculture (Washington, DC). The authors thank Francisco Leal Yepes, Charlene Ryan, Rheanna Foley, and Elizabeth Martens (Cornell University), as well as Mélissa Dupléssis (Université Laval, Quebec, Canada) for their help with sample collection. We acknowledge the technical assistance of Courtney Preseault and Carolina Ferreira (Michigan State University) for milk fatty acid analysis.

\section{REFERENCES}

Barbano, D. M., P. Cree, T. R. Overton, H. M. Dann, and R. J. Grant. 2015. Prediction of blood nonesterified fatty acid (NEFA) by FTIR analysis of individual cow milk samples. J. Dairy Sci. 98(Suppl. 2):553. (Abstr.)

Barbano, D. M., C. Melilli, and T. R. Overton. 2014. Advanced Use of FTIR Spectra of Milk for Feeding and Health Management. Pages 105-113 in Proc. Cornell Nutrition Conference for Feed Manufacturers, Syracuse, NY. Cornell University, Ithaca, NY.

Bauman, D. E., L. H. Baumgard, B. A. Corl, and J. M. Griinari. 1999. Biosynthesis of conjugated linoleic acid in ruminants. Pages 1-11 in Proc. American Society of Animal Science, Indianapolis, IN. Am. Soc. Anim. Sci., Champaign, IL.

Bauman, D. E., I. H. Mather, R. J. Wall, and A. L. Lock. 2006. Major advances associated with the biosynthesis of milk. J. Dairy Sci. 89:1235-1243. http://dx.doi.org/10.3168/jds.S00220302(06)72192-0.

Chapinal, N., M. Carson, T. F. Duffield, M. Capel, S. Godden, M. Overton, J. E. Santos, and S. J. LeBlanc. 2011. The association of serum metabolites with clinical disease during the transition period. J. Dairy Sci. 94:4897-4903. http://dx.doi.org/10.3168/ jds.2010-4075.

Contreras, G. A., N. J. O'Boyle, T. H. Herdt, and L. M. Sordillo. 2010. Lipomobilization in periparturient dairy cows influences the composition of plasma nonesterified fatty acids and leukocyte phospholipid fatty acids. J. Dairy Sci. 93:2508-2516. http://dx.doi. org/10.3168/jds.2009-2876.

Dohoo, I., W. Martin, and H. Stryhn. 2009. Screening and diagnostic tests. Page 111 in Veterinary Epidemiologic Research. Vol. 1. 2nd ed. S. M. McPike, ed. VER Inc., Charlottetown, Prince Edward Island, Canada.

Duffield, T. F., D. F. Kelton, K. E. Leslie, K. D. Lissemore, and J. H. Lumsden. 1997. Use of test day milk fat and milk protein to detect subclinical ketosis in dairy cattle in Ontario. Can. Vet. J. 38:713-718.

Duffield, T. F., K. D. Lissemore, B. W. McBride, and K. E. Leslie 2009. Impact of hyperketonemia in early lactation dairy cows on health and production. J. Dairy Sci. 92:571-580. http://dx.doi. org/10.3168/jds.2008-1507.

Gillis, A. T., N. A. M. Eskin, and R. L. Cliplef. 1973. Fatty acid composition of bovine intramuscular and subcutaneous fat as related to breed and sex. J. Food Sci. 38:408-411. http://dx.doi. org/10.1111/j.1365-2621.1973.tb01441.x.

Gross, J., H. A. van Dorland, R. M. Bruckmaier, and F. J. Schwarz 2011. Milk fatty acid profile related to energy balance in dairy cows. J. Dairy Res. 78:479-488. http://dx.doi.org/10.1017/ S0022029911000550.

Hamann, J., and V. Krömker. 1997. Potential of specific milk composition variables for cow health management. Livest. Prod. Sci. 48:201-208. 10.1016/S0301-6226(97)00027-4.

Harfoot, C. G. 1981. Lipid metabolism in the rumen. Pages 21-56 in Lipid Metabolism in Ruminant Animals. Vol. 1. W. W. Christie, ed. Pergamon Press, Elmsford, NY.

Iwersen, M., U. Falkenberg, R. Voigtsberger, D. Forderung, and W. Heuwieser. 2009. Evaluation of an electronic cowside test to de- 
tect subclinical ketosis in dairy cows. J. Dairy Sci. 92:2618-2624. http://dx.doi.org/10.3168/jds.2008-1795.

Iwersen, M., D. Klein-Jobstl, M. Pichler, L. Roland, B. Fidlschuster, I. Schwendenwein, and M. Drillich. 2013. Comparison of 2 electronic cowside tests to detect subclinical ketosis in dairy cows and the influence of the temperature and type of blood sample on the test results. J. Dairy Sci. 96:7719-7730. http://dx.doi.org/10.3168/ jds.2013-7121.

Jorjong, S., A. T. van Knegsel, J. Verwaeren, R. M. Bruckmaier, B. De Baets, B. Kemp, and V. Fievez. 2015. Milk fatty acids as possible biomarkers to diagnose hyperketonemia in early lactation. J. Dairy Sci. 98:5211-5221. http://dx.doi.org/10.3168/jds.2014-8728.

Jorjong, S., A. T. van Knegsel, J. Verwaeren, M. V. Lahoz, R. M. Bruckmaier, B. De Baets, B. Kemp, and V. Fievez. 2014. Milk fatty acids as possible biomarkers to early diagnose elevated concentrations of blood plasma nonesterified fatty acids in dairy cows. J. Dairy Sci. 97:7054-7064. http://dx.doi.org/10.3168/jds.2014-8039.

Krogh, M. A., N. Toft, and C. Enevoldsen. 2011. Latent class evaluation of a milk test, a urine test, and the fat-to-protein percentage ratio in milk to diagnose ketosis in dairy cows. J. Dairy Sci. 94:2360-2367. http://dx.doi.org/10.3168/jds.2010-3816.

Lock, A. L., C. L. Preseault, J. E. Rico, K. E. DeLand, and M. S. Allen. 2013. Feeding a C16:0-enriched fat supplement increased the yield of milk fat and improved conversion of feed to milk. J. Dairy Sci. 96:6650-6659. http://dx.doi.org/10.3168/jds.2013-6892.

Mahrt, A., O. Burfeind, R. Voigtsberger, A. Muller, and W. Heuwieser. 2014. (Evaluation of a new electronic handheld meter for measurement of beta-hydroxybutyric acid in dairy cows). Tierarztl. Prax. Ausg. G Grosstiere Nutztiere. 42:5-10. (In German)

Mann, S., F. A. Leal Yepes, T. R. Overton, A. L. Lock, S. V. Lamb, J. J. Wakshlag, and D. V. Nydam. 2016. Effect of dry period dietary energy level in dairy cattle on volume, concentration of IgG, insulin and fatty acid composition of colostrum. J. Dairy Sci. 99:1515-1526. http://dx.doi.org/10.3168/jds.2015-9926.

Mann, S., F. A. Yepes, T. R. Overton, J. J. Wakshlag, A. L. Lock, C. M. Ryan, and D. V. Nydam. 2015. Dry period plane of energy: Effects on feed intake, energy balance, milk production, and composition in transition dairy cows. J. Dairy Sci. 98:3366-3382.

McArt, J. A., D. V. Nydam, and G. R. Oetzel. 2012. Epidemiology of subclinical ketosis in early lactation dairy cattle. J. Dairy Sci. 95:5056-5066. http://dx.doi.org/10.3168/jds.2012-5443.

McCarthy, M. M., S. Mann, D. V. Nydam, T. R. Overton, and J. A. McArt. 2015. Short communication: Concentrations of nonesterified fatty acids and beta-hydroxybutyrate in dairy cows are not well correlated during the transition period. J. Dairy Sci. 98:62846290. http://dx.doi.org/10.3168/jds.2015-9446.
Nogalski, Z., M. Wronski, M. Sobczuk-Szul, M. Mochol, and P. Pogorzelska. 2012. The effect of body energy reserve mobilization on the fatty acid profile of milk in high-yielding cows. Asian-australas. J. Anim. Sci. 25:1712-1720.

Ospina, P. A., J. A. McArt, T. R. Overton, T. Stokol, and D. V. Nydam. 2013. Using nonesterified fatty acids and beta-hydroxybutyrate concentrations during the transition period for herd-level monitoring of increased risk of disease and decreased reproductive and milking performance. Vet. Clin. North Am. Food Anim. Pract. $29: 387-412$.

Ospina, P. A., D. V. Nydam, T. Stokol, and T. R. Overton. 2010. Evaluation of nonesterified fatty acids and beta-hydroxybutyrate in transition dairy cattle in the northeastern United States: Critical thresholds for prediction of clinical diseases. J. Dairy Sci. 93:546-554. http://dx.doi.org/10.3168/jds.2009-2277.

Palmquist, D. L. 2006. Milk fat: Origin of fatty acids and influence of nutritional factors thereon. Pages 43-92 in Advanced Dairy Chemistry Lipids. Vol. 2. P. F. Fox and P. L. H. McSweeney, ed. Springer, New York, NY.

Palmquist, D. L., A. L. Lock, K. J. Shingfield, and D. E. Bauman. 2005. Biosynthesis of conjugated linoleic acid in ruminants and humans. Pages 179-217 in Advances in Food and Nutrition Research. Vol. 50. Academic Press, Cambridge, MA.

Suthar, V. S., J. Canelas-Raposo, A. Deniz, and W. Heuwieser. 2013. Prevalence of subclinical ketosis and relationships with postpartum diseases in European dairy cows. J. Dairy Sci. 96:2925-2938. http://dx.doi.org/10.3168/jds.2012-6035.

Swets, J. A. 1988. Measuring the accuracy of diagnostic systems. Science 240:1285-1293.

Toni, F., L. Vincenti, L. Grigoletto, A. Ricci, and Y. H. Schukken. 2011. Early lactation ratio of fat and protein percentage in milk is associated with health, milk production, and survival. J. Dairy Sci. 94:1772-1783. http://dx.doi.org/10.3168/jds.2010-3389.

Van Haelst, Y. N., A. Beeckman, A. T. Van Knegsel, and V. Fievez. 2008. Short communication: Elevated concentrations of oleic acid and long-chain fatty acids in milk fat of multiparous subclinical ketotic cows. J. Dairy Sci. 91:4683-4686. http://dx.doi.org/10.3168/ jds.2008-1375.

Vlaeminck, B., V. Fievez, A. R. J. Cabrita, A. J. M. Fonseca, and R. J. Dewhurst. 2006. Factors affecting odd- and branched-chain fatty acids in milk: A review. Anim. Feed Sci. Technol. 131:389-417. http://dx.doi.org/10.1016/j.anifeedsci.2006.06.017.

Woolpert, M. E., C. Melilli, K. W. Cotanch, H. M. Dann, R. J. Grant, L. E. Chase, and D. M. Barbano. 2015. Effect of nutrition and management practices on de novo fatty acid synthesis in northeastern US dairy herds. J. Dairy Sci. 98(Suppl. 1):212. (Abstr.) 